\title{
POLLINATORS OF LUPIN, Lupinus termis Forssk. AND THEIR EFFECT ON ITS YIELD
}

(Received: 8.3.2009)

\author{
By \\ I. M. A. Ebadah*, A. M. Khater and H. M. Mansour \\ * National Research Center, Dokki, Giza, Egypt. \\ Plant Protection Research Institute, Agricultural Research Center, Dokki, Giza, Egypt
}

\begin{abstract}
The present investigation aimed to survey the insect pollinators of lupin (Lupinus termis Forssk.) and their effect on the yield during flowering periods of 2005/2006 and 2006/2007 seasons at Shalakan district, Kalubia Governorate.

Obtained results indicated that the total insect counts attained 17 species, belong to five orders; Hemiptera (2 species), Lepidoptera (2 species), Coleoptera (3 species), Diptera (6 species) and Hymenoptera (4 species). In particular, honeybees, Apis mellifera L. proved to be the most insect pollinators, constituting 14.66, and $18.59 \%$ of the total insect count in the two seasons, respectively. The highest bee number was detected around mid seasons and at 12-2 p.m. Prevailing air temperature and R.H. \% affected moderatly the occurrence of insect pollinators.

The presence of insect pollinators during the flowering period of lupin increased significantly most yield parameters such as the number of pods/plant, the number of seeds/pod, the number of seeds/plant and weight of seeds/plant. On the contrary, insect exclusion caused the inverse. As a result the estimated seed yield/feddan attained $1631.95,868.8$ and $1366.87 \mathrm{~kg}$ for open pallination, insect exclusion and honeybee pollination, respectively.
\end{abstract}

Key words: coleoptera, hymenoptera,lupin, pollination, pollinators, seed yield.

\section{INTRODUCTION}

In Egypt, lupin (Lupinus termis Forssk.) is one of the most important leguminous crops, It is used as a common good source of protein and industrial drugs. Insect pollinators play an essential role in increasing the productivity of field and horticultural crops, without displacing other necessary farm commodities. This role could be attributed to the efficiency of pollinating insects in increasing both self-fertilization (Pazy, 1984; Almeida and De Maltez, 1979) and cross pollination which promotes hybrid vigor (Langridge and Goodmann, 1985 and YousifKhalil et al, 1989).

The present work was carried out to survey insect pollinators of lupin along with their foraging behaviour. In addition, the effects of open pollination, insect exclusion and honeybee pollination on the yield parameters of lupin were also taken in account during the two successive seasons of 2005/2006 and 2006/2007.

\section{MATERIALS AND METHODS}

The present study was carried out at Shalakan district, Kalubia Governorate. The experiments were performed during the two successive agricultural winter seasons of 2005/2006 and
$2006 / 2007$ to survey insect pollinators of lupin and there effects on lupin yield.

\subsection{Insect pollinators of lupin and their foraging behaviour}

Seeds of lupin (Lupinus termis Forssk.) cultivar Giza 1 were planted in an area of half feddan on October 12, 2005 and on October 9, 2006 at Shalakan district. The crop was grown in rows $60 \mathrm{~cm}$ wide and seeds were sown in hills, 30 $\mathrm{cm}$ apart. One plant was left in each hill. Normal agricultural practices were applied without any insecticidal application.

Insects visiting lupin plants were collected during the flowering period which started from January 17 to February 28, 2006 and from January 15 to February 26, 2007. Surveyed insects were taken a day weekly at two-hour intervals, starting from 8 a.m. until 4 p.m., using a common insect net. Fifty double sweeps were made at each interval. The surveyed insects were started and identified to genera and species when possible, climatic factors including, ambient air temperature and relative humidity (R.H. \%) were recorded at each interval.

The correlation coefficient values between the number of surveyed insects and each of 
temperature degrees and $\mathrm{RH} \%$ were calculated according to Snedecor (1957).

\subsection{Effect of insect pollination on the yield of lupin}

\subsubsection{Experimental fields}

To determine the effect of open pollination, insect exclusion and honeybee pollination on the yield of lupin, nine $1.5 \times 1.5 \mathrm{~m}$ random plots cultivated with lupin were used as follows:

1. Three open plots were left for open pollination (as control) (A).

2. Three plots were covered with plastic screen cages $1.5 \times 1.5 \times 1.5 \mathrm{~m}$ to exclude all insect visit (B).

3. Three plots as in (B) but each was provided with honeybee nucleus. (honeybee pollination) (C).

\subsubsection{The plastic screen cages}

Wooden frame cage measuring $1.5 \times 1.5 \times 1.5$ $m$ was covered with plastic screen of 14 mesh/square inch and had a door to permit observation of plants and honeybees inside the cage, such cages were randomaly distributed on the cultivated area. The cages were placed on the field at the beginning of the flowering period until its end.

\subsubsection{Honeybee nuclei}

Three nuclei were used, each nucleus contained 2 combs, one of which contained sealed brood and the other contained stored honey, each nucleus was headed by sister mated queens (Carniolan hybrid ). Sugar syrup $\left(1^{\mathrm{s}}: 1^{\mathrm{w}}\right)$ was used for out door artificial feeding and inside the cages when necessary.

The following yield parameters were recorded during the two successive seasons:

- Total number of flowers per plant

- Total number of pods per plant

-Mean percentage of pod set $=$

\section{Total number of pods} $\times 100$

Total number of flower/plant

- Mean number of seeds per pod

- Mean number of seeds per plant

- Mean weight of seeds per plant (g)

- Mean weight of 100 seeds (g)

- Estimated seed yield/feddan $\left(4200 \mathrm{~m}^{2}\right) \mathrm{kg}$.

Data obtained were statistically analysed according to the methods of Snedecor (1957).

\section{RESULTS AND DISCUSSION 3.1. Survey of lupin insect pollinators}

Insect visitors of lupin were collected at two hour interval a day weekly from 8 a.m. to 4. p.m during the blooming periods of 2005/2006 and $2006 / 2007$ seasons. These visitors were found belonging to five orders, i.e., Hemiptera (2 species), Lepidoptera (2 species), Coleoptera (3 species), Diptera (6 species) and Hymenoptera (4 species) (Table 1).

Hemipterous insects, represented by Oxycarenus hyalinipemnnis and Nezara viridula, formed 4.02 and $6.20 \%$ of the total visitors in the flowering periods of 2006 and 2007 seasons, respectively.

Lepidopterious insects, represented by Syngrapha circumflexa and Polymatus baeticus formed 4.24 and $4.93 \%$ of the total insect count in the two seasons of the study, respectively. The Syngrapha sp. and Polymatus baeticus were more abundant at 12 noon to 2 p.m. (Table 2).

Coleopterous insects represented 6.77 and $7.16 \%$ of the total catch in the two seasons respectively. This order was represented by 3 species Coccinella undcimpunctata, Sitona lividipes and Tropinota squalida.

Insects belonging to order Diptera represented $59.67,53.44 \%$ of the total collected insects in the two seasons, respectively (Table 1). Daily peak activity of flies on lupin flowers was detected at 12 noon in both seasons (Table 2). Melanagromyza phaseoli was the most abundant species, followed by Phytomyza atricontis and Musca domestia. The respective percentages of occurrence of the three species were $15.63,13.69$ and $12.20 \%$ in 2006 and 13.26, 11.42 and 12.20 $\%$ in 2007 flowering season.

The total numbers of hymenopterus insects were 346 and 292 insects, representing 25.30 and $28.28 \%$ of the total insect collected in the two seasons, respectively (Table 1). The surveyed insects were (4 species) i.e. honeybees, Apis mellifera (14.66 and 18.59\%); Megachile submucida (3.57 and $3.97 \%$ ); Anthophora sp. (3.13 and $2.90 \%$ ) and Polistes gollicus (3.94 and $2.81 \%$ ) of the total insect visitors in the two seasons, respectively. These results are similar to those of Wainwright (1978 a, b) Stoddard (1991) and Yousif-Khalil et al. (1992) who worked on varied plant species.

Data obtained showed that honey bees were the most abundant lupin visitors, being more active during the first half of February. The daily peak activity of honeybee on lupin blossoms was detected between 12.00 noon and 2 p.m. (Table 2).

Similar results were also reported by Voluzneve (1971); Stoddard (1991); and Wainwright (1978 a, b).

The correlation coefficient value between air temperature and the number of collected insects recorded 0.12 and 0.53 in the two seasons, respectively. Correlation coefficient values (r) between R.H \% and the number of insect visitors 
Pollinators of lupin, Lupinus termis Forssk and their .

Table (1): Lupin insect visitors collected a day weekly during the flowering seasons of 2006 and 2007 at Kalubia Governorate

\begin{tabular}{|c|c|c|c|c|c|c|c|c|c|c|c|c|c|c|c|c|c|c|}
\hline \multirow{2}{*}{$\begin{array}{c}\text { Year } \\
\text { Date } \\
\text { Insect }\end{array}$} & \multicolumn{9}{|c|}{2006} & \multicolumn{9}{|c|}{2007} \\
\hline & $17 / 1$ & $24 / 1$ & $31 / 1$ & $7 / 2$ & $14 / 2$ & $21 / 2$ & $28 / 2$ & Total & $\%$ & $15 / 1$ & $22 / 1$ & $29 / 1$ & $5 / 2$ & $12 / 2$ & $19 / 2$ & $26 / 2$ & Total & $\%$ \\
\hline \multicolumn{19}{|l|}{ Order: Hemiptera } \\
\hline Oxycarenus hyalinipennis & - & 3 & 7 & 6 & 1 & 1 & - & 18 & 1.34 & 2 & 4 & 6 & 5 & - & 2 & 2 & 21 & 2.03 \\
\hline Nezara viridula $\mathrm{L}$. & 3 & 4 & 1 & 5 & 9 & 7 & 7 & 36 & 2.68 & 3 & 5 & 7 & 4 & 8 & 10 & 6 & 43 & 4.16 \\
\hline Total Hemipterous insects & 3 & 7 & 8 & 11 & 10 & 8 & 7 & 54 & 4.02 & 5 & 9 & 13 & 9 & 8 & 12 & 8 & 64 & 6.20 \\
\hline \multicolumn{19}{|l|}{ Order: Lepidoptera } \\
\hline Syngrapha circumflexa $\mathrm{L}$. & - & 2 & 2 & 5 & 4 & 3 & 1 & 17 & 1.26 & - & 1 & 4 & 3 & 5 & 2 & - & 15 & 1.45 \\
\hline Polymatus baeticus $\mathrm{L}$. & 4 & 3 & 7 & 10 & 6 & 8 & 2 & 40 & 2.98 & - & 5 & 9 & 8 & 12 & 2 & - & 36 & 3.48 \\
\hline Total lepidopterous insects & 4 & 5 & 9 & 15 & 10 & 11 & 3 & 57 & 4.24 & - & 6 & 13 & 11 & 17 & 4 & - & 51 & 4.93 \\
\hline \multicolumn{19}{|l|}{ Order: Coleoptera } \\
\hline Coccinella undecimpunctata & 3 & 7 & 11 & 4 & 6 & 6 & 10 & 47 & 3.50 & - & 4 & 9 & 7 & 8 & 3 & 2 & 33 & 3.19 \\
\hline Sitona lividipes & 3 & 1 & 5 & 2 & 4 & - & 3 & 18 & 1.43 & - & - & 4 & 3 & 10 & 2 & 3 & 22 & 2.13 \\
\hline Tropinota squalida & 6 & 6 & 4 & 5 & 2 & 3 & - & 26 & 1.93 & - & - & 4 & 5 & 3 & 7 & - & 19 & 1.84 \\
\hline Total Coleopterous insects & 12 & 14 & 20 & 11 & 12 & 9 & 13 & 91 & 6.77 & - & 4 & 17 & 15 & 21 & 12 & 5 & 74 & 7.16 \\
\hline \multicolumn{19}{|l|}{ Order: Diptera } \\
\hline Syrphus corollae & 4 & 4 & 5 & 9 & 13 & 7 & 6 & 48 & 3.57 & - & 2 & 7 & 6 & 11 & 3 & 10 & 39 & 3.78 \\
\hline Liriomyza congesta & 13 & 18 & 15 & 12 & 19 & 20 & 22 & 119 & 8.85 & 12 & 11 & 10 & 7 & 6 & 17 & 15 & 78 & 7.55 \\
\hline Melanagromza phaseoli & 32 & 23 & 46 & 44 & 28 & 23 & 14 & 210 & 15.63 & 12 & 18 & 24 & 19 & 21 & 16 & 17 & 137 & 13.26 \\
\hline Phytonyza atricontis & 16 & 21 & 34 & 45 & 37 & 13 & 18 & 184 & 13.69 & 7 & 12 & 17 & 33 & 29 & 15 & 5 & 118 & 11.42 \\
\hline Musca domestica & 14 & 26 & 15 & 21 & 44 & 20 & 24 & 164 & 12.20 & 15 & 21 & 29 & 12 & 19 & 8 & 22 & 126 & 12.20 \\
\hline Sarcophaga carnaria & 13 & 19 & 7 & 16 & 10 & 8 & 4 & 77 & 5.73 & 10 & 3 & 5 & 13 & 7 & 11 & 5 & 54 & 5.23 \\
\hline Total Dipterous insects & 92 & 111 & 122 & 147 & 151 & 91 & 88 & 802 & 59.69 & 56 & 67 & 92 & 90 & 93 & 80 & 74 & 552 & 53.44 \\
\hline \multicolumn{19}{|l|}{ Order: Hymenoptera } \\
\hline Apis mellifera & 4 & 22 & 35 & 58 & 39 & 17 & 22 & 197 & 14.66 & 21 & 17 & 28 & 36 & 47 & 19 & 24 & 192 & 18.59 \\
\hline Megachile submucida & 6 & 2 & 4 & 10 & 14 & 5 & 7 & 48 & 3.57 & - & 5 & 7 & 11 & 7 & 9 & 2 & 41 & 3.97 \\
\hline Anthophora sp. & 3 & 4 & 5 & 8 & 13 & 7 & 2 & 42 & 3.13 & - & 4 & 5 & 13 & 6 & 2 & - & 30 & 2.90 \\
\hline Polistes gallicus & 3 & 5 & 11 & 14 & 9 & 7 & 4 & 53 & 3.94 & - & 2 & - & 3 & 10 & 8 & 6 & 29 & 2.81 \\
\hline Total Hymenopterous insects & 16 & 33 & 55 & 90 & 75 & 36 & 35 & 340 & 25.30 & 21 & 28 & 40 & 63 & 70 & 38 & 32 & 292 & 28.27 \\
\hline General Total & 127 & 170 & 214 & 274 & 258 & 155 & 146 & 1344 & & 82 & 114 & 175 & 188 & 209 & 146 & 119 & 1033 & \\
\hline Mean tem. $\left({ }^{\circ} \mathrm{C}\right)$ & 13.25 & 15.0 & 13.43 & 16.37 & 16.53 & 16.30 & 18.78 & \multicolumn{2}{|c|}{$\mathrm{r}_{1}=0.12$} & 16.14 & 15.86 & 16.29 & 13.4 & 14.71 & 17.28 & 19.57 & \multicolumn{2}{|c|}{$\mathrm{r}_{1}=0.53$} \\
\hline Mean R.H. \% & 67.75 & 66.29 & 63.14 & 58.0 & 66.67 & 66.71 & 64.00 & \multicolumn{2}{|c|}{$r_{2}=-0.64$} & 63.40 & 63.60 & 59.60 & 67.6 & 67.40 & 65.30 & 66.4 & \multicolumn{2}{|c|}{$r_{2}=-0.28$} \\
\hline
\end{tabular}

$\mathrm{r} 1=$ Correlation coefficient value between air temperature and the number of insects.

$\mathrm{r} 2=$ Correlation coefficient value between air R. H. \% and the number of insects 
Table (2): Daily activity of lupin pollinators at two-hour intervals during the flowering seasons of 2006 and 2007.

\begin{tabular}{|c|c|c|c|c|c|c|c|c|c|c|c|c|c|c|}
\hline Year & \multicolumn{7}{|c|}{2006} & \multicolumn{7}{|c|}{2007} \\
\hline $\begin{array}{l}\text { Time of the day } \\
\text { Insect species }\end{array}$ & 8 a.m. & 10 & 12 & 2 & 4 & Total & $\%$ & 8 a.m. & 10 & 12 & 2 & 4 & Total & $\%$ \\
\hline \multicolumn{15}{|l|}{ Order: Hemiptera } \\
\hline Oxycarenus hyalinipennis & - & 3 & 8 & 5 & 2 & 18 & 1.34 & - & 2 & 6 & 12 & 1 & 21 & 2.03 \\
\hline Nezara viridula $\mathrm{L}$. & 4 & 6 & 12 & 9 & 5 & 36 & 2.68 & 5 & 7 & 9 & 16 & 6 & 43 & 4.16 \\
\hline Total Hemipterous insects & 4 & 9 & 20 & 14 & 7 & 54 & 4.02 & 5 & 9 & 15 & 28 & 7 & 64 & 6.20 \\
\hline \multicolumn{15}{|l|}{ Order: Lepidoptera } \\
\hline Syngrapha circumflexa & - & 2 & 7 & 5 & 3 & 17 & 1.26 & - & - & 4 & 9 & 2 & 15 & 1.45 \\
\hline Polymatus baeticus & 1 & 4 & 17 & 11 & 7 & 40 & 2.98 & - & 6 & 13 & 16 & 1 & 36 & 3.48 \\
\hline Total lepidopterous insects & 1 & 6 & 24 & 16 & 10 & 57 & 4.24 & - & 6 & 17 & 25 & 3 & 51 & 4.93 \\
\hline \multicolumn{15}{|l|}{ Order: Coleoptera } \\
\hline Coccinella undecimpunctata & 4 & 11 & 18 & 10 & 4 & 47 & 3.50 & - & 3 & 18 & 7 & 5 & 33 & 3.19 \\
\hline Sitona lividipes & 2 & 3 & 4 & 6 & 3 & 18 & 1.34 & - & 5 & 3 & 8 & 6 & 22 & 2.13 \\
\hline Tropinota squalida & - & 3 & 8 & 9 & 6 & 26 & 1.93 & - & - & 3 & 12 & 4 & 19 & 1.84 \\
\hline Total Coleopterous & 6 & 17 & 30 & 25 & 13 & 91 & 6.77 & - & 8 & 14 & 27 & 15 & 74 & 7.16 \\
\hline \multicolumn{15}{|l|}{ Order: Diptera } \\
\hline Syrphus corollae & 3 & 7 & 13 & 17 & 8 & 48 & 3.57 & - & 5 & 10 & 13 & 11 & 39 & 3.78 \\
\hline Liriomyza congesta & 8 & 19 & 37 & 38 & 17 & 119 & 8.85 & 4 & 20 & 23 & 22 & 9 & 78 & 7.55 \\
\hline Melanagromza phaseoli & 14 & 33 & 69 & 65 & 29 & 210 & 15.63 & 7 & 18 & 61 & 34 & 17 & 137 & 13.26 \\
\hline Phytonyza atricontis & 9 & 28 & 50 & 57 & 40 & 184 & 13.69 & 5 & 13 & 36 & 39 & 25 & 118 & 11.42 \\
\hline Musca domestica & 18 & 36 & 52 & 42 & 16 & 164 & 12.20 & 13 & 26 & 41 & 32 & 14 & 126 & 12.20 \\
\hline Sarcophaga carnaria & 5 & 10 & 38 & 11 & 13 & 77 & 5.73 & - & 8 & 20 & 16 & 10 & 54 & 5.23 \\
\hline Total Dipterous insects & 57 & 133 & 259 & 230 & 123 & 802 & 59.67 & 29 & 90 & 191 & 156 & 86 & 552 & 53.44 \\
\hline \multicolumn{15}{|l|}{ Order: Hymenoptera } \\
\hline Apis mellifera & 10 & 29 & 55 & 62 & 41 & 197 & 14.66 & 7 & 36 & 48 & 58 & 43 & 192 & 18.59 \\
\hline Megachile submucida & 4 & 12 & 16 & 9 & 7 & 48 & 3.57 & - & 6 & 16 & 10 & 9 & 41 & 3.97 \\
\hline Anthophora sp. & 3 & 7 & 14 & 14 & 4 & 42 & 3.13 & - & 7 & 8 & 12 & 3 & 30 & 2.90 \\
\hline Polistes gallicus & 5 & 10 & 17 & 12 & 9 & 53 & 3.94 & 2 & 7 & 6 & 13 & 1 & 29 & 2.81 \\
\hline Total Hymenopterous insects & 22 & 58 & 102 & 97 & 61 & 340 & 25.30 & 9 & 56 & 78 & 93 & 56 & 292 & 28.27 \\
\hline General Total & & & & & & 1344 & & & & & & & 1033 & \\
\hline
\end{tabular}


Table (3): Data of the Lupinus termis Forssk. yield as influenced by open-pollination (A), insect exclusion (B) and honeybee pollination (C) at Kalubia Governorate during 2006 and 2007 seasons.

\begin{tabular}{|c|c|c|c|c|c|c|c|c|c|c|}
\hline Year & \multicolumn{5}{|c|}{2006} & \multicolumn{5}{|c|}{2007} \\
\hline \multirow{2}{*}{ Treatments } & \multirow{2}{*}{$\mathbf{A}$} & \multirow{2}{*}{ B } & \multirow{2}{*}{$\mathbf{C}$} & \multicolumn{2}{|c|}{ LSD } & \multirow{2}{*}{$\mathbf{A}$} & \multirow{2}{*}{$\mathbf{B}$} & \multirow{2}{*}{$\mathbf{C}$} & \multicolumn{2}{|c|}{ LSD } \\
\hline & & & & $5 \%$ & $1 \%$ & & & & $5 \%$ & $1 \%$ \\
\hline Mean number of flowers/plant & 131.93 & 132.72 & 127.29 & - & - & 133.63 & 124.03 & 129.48 & - & - \\
\hline Mean percentage of pod set & 33.02 & 19.71 & 31.47 & 4.10 & 6.80 & 31.33 & 22.88 & 29.93 & 1.90 & 3.21 \\
\hline Mean number of pods/plant & 42.48 & 26.26 & 39.77 & 3.12 & 5.18 & 41.97 & 25.93 & 38.72 & 3.50 & 5.81 \\
\hline Mean number of seeds/pod & 3.19 & 1.80 & 2.82 & 0.70 & 1.20 & 3.17 & 2.22 & 2.77 & 0.67 & 1.11 \\
\hline Mean number of seeds/plant & 84.6 & 40.77 & 64.73 & 6.20 & 10.30 & 87.60 & 38.17 & 67.24 & 6.15 & 10.54 \\
\hline Mean weight of seeds/plant (g) & 33.33 & 16.07 & 25.50 & 2.44 & 4.06 & 34.49 & 18.85 & 26.15 & 1.90 & 3.10 \\
\hline Mean weight of 100 seeds (g) & 37.35 & 31.30 & 34.02 & - & - & 36.15 & 29.14 & 32.75 & - & - \\
\hline Calculated seed yield/feddan $(\mathrm{kg})$ & 1601.80 & 856.9 & 1360.03 & 230.58 & 383.11 & 1662.1 & 880.7 & 1373.7 & 108.00 & 179.40 \\
\hline
\end{tabular}

Two - year mean of seed yield/feddan $(\mathrm{kg})$

\begin{tabular}{|c|c|c|c|c|c|c|}
\hline \multirow{2}{*}{ Treatments } & \multicolumn{2}{|c|}{ A } & \multicolumn{2}{c|}{ B } & \multicolumn{2}{c|}{ C } \\
\cline { 2 - 7 } & Wt. & Control & Wt. & *Ratio \% & Wt. & *Ratio \% \\
\hline Seed yield feddan (Kg) & 1631.95 & $100 \%$ & 868.8 & 53.32 & 1366.87 & 83.76 \\
\hline
\end{tabular}

* Based on control plot as $100 \%$ 
I. M. A. Ebadah et al.,

recorded -0.64 and -0.28 in the two seasons, respectively.

\subsection{Effect of insect pollination on the yield of lupin \\ 3.2.1. Mean number of flowers}

As shown in Table (3), the mean number of flowers per plant in the open pollinated, insect protected and honeybee supplied plots were 131.93, 132.72 and 127.29 flowers, in 2006; and $133.63,124.03$ and 129.48 flowers per plant in 2007, respectively without any significant differences.

\subsubsection{Mean percentage of pod set}

Data presented in Table (3), indicate that the mean percentage of pod set recorded 33.02, 19.71 and $31.47 \%$ in 2006 , and $31.33,22.88$ and 29.93 $\%$ in 2007 season for open pollination, insect exclusion and honeybee pollination in the two seasons, respectively. Insect protected plots showed the least significant percentage of pod set in the two years of study, while the differences between open pollination and honeybee pollination were insignificant in both seasons. Similar results were reported by Almeida and De Maltez (1979), Kamler (1982), Yousif-Khalil et al. (1989) and Khater et al. (2003) who investigated varied leguminous crop.

\subsubsection{Mean number of pods/plant}

Results in Table (3), indicate that open pollinated plots produced the highest significant mean number of pods/plant in both seasons (42.48, and 41.97 pods), whereas insect excluded plots yielded the least significant mean number of pods/ plant (26.26 and 25.92 pods). On the other hand, the differences between honeybee provided plots and open pollinated plots were insignificant in both seasons. Similar conclusion was reached by Koltowski (1996 b) and Khater et al. (2003).

\subsubsection{Mean number of seeds/pod}

Obtained results indicated that the mean seeds/pod from open pollinated, insect excluded and honeybee pollinated plants recorded 3.19, 1.80 and 2.82 seeds/pod in 2006, and 3.17, 2.22 and 2.77 seeds/pod in 2007 season, respectively. Analysis of data cleared that insect exclusion acheived the least significant mean number of seeds/pod in 2006 (Table 3). The results partially agree with Koltowski (1996 b) and Richards (1997).

\subsubsection{Mean number of seeds/plant}

As shown in Table (3), open pollination yielded the highest significant mean number of seeds/plant, recording 84.60 and 87.60 seeds in the two seasons, respectively. Insect prevention induced the least significant one (40.77 and 38.17 seeds) in both seasons. These results are in accordance with those of Somerville (1994), Koltowski (1996 a \& b) and Khater et al. (2003).

\subsubsection{Mean weight of seeds/plant}

Results in Table (3) indicate that open pollination produced the highest significant mean weight of seeds/plant recording 33.33 and $37.49 \mathrm{~g}$ in both seasons, respectively. On the other hand, insect exclusion induced the least significant values (16.07 and 18.85 g.) in the two years. These results agree with Mesqaida et al.,(1992) and Khater et al., (2003).

\subsubsection{Mean weight of 100 seeds}

The mean weight of 100 seeds resulted from open pollinated, insect exclusion and honeybee pollinated plots recorded $37.35,31.30$ and $34.02 \mathrm{~g}$ in 2006, and 36.15, 29.14 and $32.75 \mathrm{~g}$ in 2007 season, respectively. The differences between treatments were insiginificant (Tale 3). These results agree with Mesqaide et al., (1992) and Khater et al. ,(2003).

\subsubsection{Estimated seed yield /feddan}

As shown in Table (3), the calculated seed yield/feddan from open pollination, insect exclusion and honeybee pollination recorded $1601.8,856.9$ and $1360.03 \mathrm{~kg}$ in 2006; and $1662.1,880.7$ and $1375.7 \mathrm{~kg}$ in 2007 seasons, respectively. Open pollination induced the highest significant calculated seed yield/fed., meanwhile, insect exclusion was the least. The two years mean seed yield/fed., recorded 1631.95, 868.8 and $1366.87 \mathrm{~kg}$. for the three treatments, respectively.

Honeybee pollination yielded as $83.76 \%$ as the seed yield of the control (open pollination), whereas insect exclusion yield as $53.32 \%$ as that of the control. These results are in parallel with those of Langridge and Goodmann (1985); Williams (1987); Koltowski (1996 b) and Khater et al. (2003).

Generally, it could be concluded that insect pollination is very important for high yield crop production and the presence of honeybee colonies is very necessary to ensure adequate pollination.

\section{REFERENCES}

Almeida J. R. and De Maltez A. G. (1979). Crosspollination of yellow lupin in Portugal. Condicaes Portuguesas, Agronomia Lusitana, 39(4): 295-304.

Kamler F. (1982). Nectar production of Vicia faba and its effects on honeybee pollination. Instytut Warzy-Wnictwa, 3 (1): 94-112. (AA. 1037/83)

Khater A. M., El-Zakardy K. A. and Ebadah I. M. A. (2003). The efficiency of honeybees and other insect pollinators in pollination of faba 
bean (Vicia faba L.). Bull. Fac. Agric., Cairo Univ., 54: 465-482.

Koltowski Z. (1996a). Foraging by pollinating insects on several field bean cultivars (Vicia faba L.). Pszczelniccz Zeszyty Naukowe, 40(1): 191-207.

Koltowski Z. (1996b). Beekeeping value and pollination requirements of several field bean cultivars. Pszczeinicze Naukowe, 40(2): 281282.

Langridge D. F. and Goodmann R. D. (1985). Honeybee pollination of lupins (Lupinus albus). Australia Journal of Experimental Agriculture 26, 220-233.

Mesqaida J., Leguen J. and Morin G. (1992). Role of Apoidea (Insecta, Hymenoptera) in pollination of spring type faba bean (Vicia faba L. var. equina Steudel). Apidologie, 23(5): 487-490.

Pazy B. (1984). Insect induced self-pollination. Plant Systematics and Evaluation, 144(3/4): 315-320.

Richards K. W. (1997). Potential of the alfalfa leaf cutler bee Megachile rotundata (F.) (Hym., Megachilidae) to pollinate hairy and winter vetches (Vicia spp.). Journal of Applied Entomology, 12(4): 225-229.

Snedecor G. W. (1957). Statistical Methods Applied to Experiments in Agriculture and Biology. The Iowa State College Press, $5^{\text {th }}$ ed. Iowa, USA.
Somerville D. (1994). Honeybees in faba bean pollination. Bee Briefs ,11(1): 13-15.

Stoddard F. L. (1991). Pollen vectors and pollination of faba beans in Southern Australia. Australian J. of Agric. Res., 42(7): 1173-1178.

Voluzneve T. A. (1971). Biology of flowering in Vicia faba L. Trudy Priklodnoi Botonike Gentetike Selektssi ,45(3): 102-109.

Wainwright G. M. (1978a). The floral biology and pollination ecology of two desert lupines. Bulletin of the Torrey Botontid Club, 105(1): 24-38.

Wainwright G. M. (1978b). Hymenoptera territorialty and its influence on the pollination ecology of Lupinus arizonicus. Southwestern Naturalist, 23(4): 606-615.

Williams I. H. (1987). The pollination of lupins. Bee World, 68(1):10-16.

Yousif-Khalil S. I., El-Shakaa M. K,, Hamdy M. K. and Ebadah I. M. A. (1992). Insect pollinators of lentil, Lens esculenta Moench and their effect on its yield. Zagazig J. Agric Res., Vol. 19(5B): 2243-2251.

Yousif-Khalil S. I., El-Zohairy M. M. and Hassan K.A. (1989). Effect of honeybees and other pollinating insects on the yield of three chickpea cultivars. Proc. $3^{\text {rd }}$ Nat. Conf. of Pests \& Dis. of Veg. \& Fruits in Egypt and Arab Count., Ismailia, Egypt, 338-347.

$$
\begin{aligned}
& \text { ملقحات الترمس وتتأثيرها على المحصول } \\
& \text { إبراهيم محمد عبد المنعم عبادة * ـ على محمد خاطر - حمدى متولى منصور }
\end{aligned}
$$

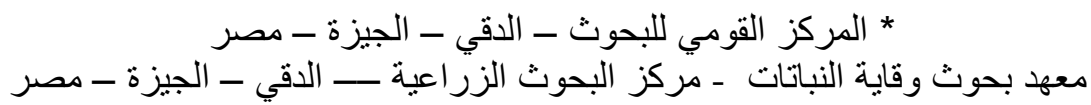

$$
\begin{aligned}
& \text { ملخص الحتر }
\end{aligned}
$$

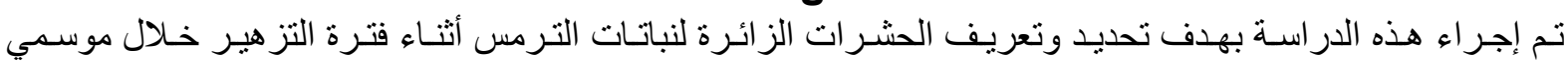

$$
\begin{aligned}
& \text { 2006/2005، و 2007/2006 بناحية شلقان بمحافظة القلو بية. القان. }
\end{aligned}
$$

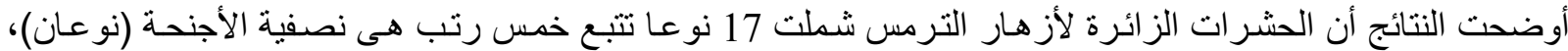

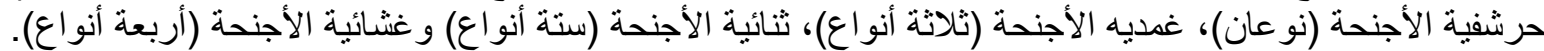

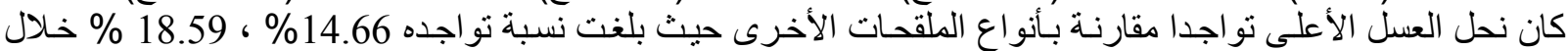

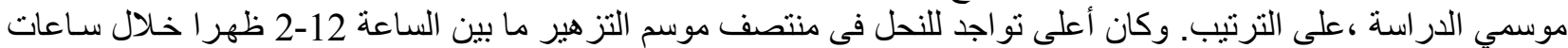

$$
\begin{aligned}
& \text { النهار. } \\
& \text { ولقد اتضح وجود نأثير ا منوسطا لدرجات الحر ارة (موجبا) ونسبة الرطوبـة (سـالبا) على تعداد الحشر ات الزائرة لأزهار }
\end{aligned}
$$

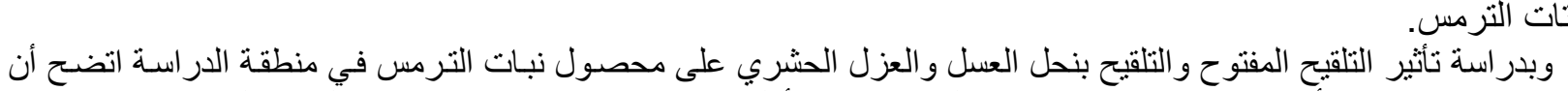

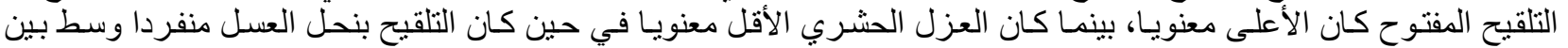

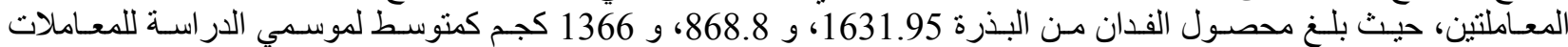

$$
\begin{aligned}
& \text { المتروكة للتلقيح المفتوح و المعزولة حشريا وتللك التي لقحت بنحل العسل على الترتيب. }
\end{aligned}
$$

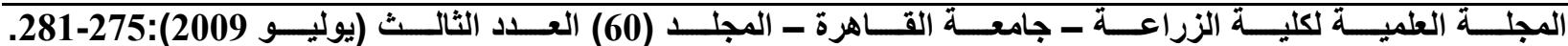


